\title{
EFFECT OF AUTHENTICAL ASSESSMENT AND HIGH ORDER THINKING SKILL (HOTS) AGAINST TROUBLESHOOTING PHYSICAL PROBLEMS (An Experiment in The Students of SMA Negeri 2 Depok City)
}

\author{
Eni Widyastuti \\ SMAN 2 Kota Depok
}

\begin{abstract}
This research aims to see the effect of authenticity and high order thinking skill (HOTS) on the problem solving of physics. Authentic assessment forms include performance and portfolio. High order thinking skill (HOTS) includes high order thinking skill (HOTS) high and high order thinking skill (HOTS) low. The method of research uses an experimental method. While the design of research uses treatment by level $2 \times 2$. The hypotheses of research were tested using two way of analysis of variance (ANAVA). The result of research concluded that: $(I)$ the results of students 'group physics problem solving abilities that were given an authentic form of higher-performing performance than the students' group physics problem solving abilities that were given an authentic portfolio assessment form; (2) there was a significant interaction effect between the authentic form of assessment and high order thinking skill (HOTS) to the results of physics problem solving ability; (3) special group of students who have high order thinking skill (HOTS) high, the result of problem solving ability of physics group of students who are given form of authentic assessment of performance is higher than the result of problem solving problem of physics group of students; (4) special group of students who have high order thinking skill (HOTS) is low, the result of problem solving ability of physics group of students who are given the form of authentic assessment of performance is lower than the result of the problem solving ability of the physics group of students who are given the form assessment a portfolio utilities.
\end{abstract}

\section{Keywords}

authentic form of assessment, high order thinking skill (HOTS), result of physics problem solving, performance and portfolio.

\begin{abstract}
ABSTRAK
Penelitian ini bertujuan untuk melihat pengaruh penilaian autentik dan high order thinking skill (HOTS) terhadap pemecahan masalah Fisika. Bentuk penilaian autentik mencakup kinerja dan portofolio. high order thinking skill (HOTS) mencakup high order thinking skill (HOTS) tinggi dan high order thinking skill (HOTS) rendah. Metode yang digunakan adalah treatment by level $2 \times 2$. Hipotesis penelitian diuji dengan menggunakan analisis varian (ANAVA) dua jalan. Hasil penelitian menyimpulkan bahwa: (I) hasil kemampuan pemecahan masalah Fisika kelompok siswa yang diberi bentuk penilaian autentik kinerja lebih tinggi dari hasil kemampuan pemecahan masalah Fisika kelompok siswa yang diberi bentuk penilaian autentik portofolio; (2) terdapat pengaruh interaksi yang signifikan antara bentuk penilaian autentik dan high order thinking skill (HOTS) terhadap hasil kemampuan pemecahan masalah Fisika; (3) khusus kelompok siswa yang memiliki high order thinking skill (HOTS) tinggi, hasil kemampuan pemecahan masalah Fisika kelompok siswa yang diberi bentuk penilaian autentik kinerja lebih tinggi dari hasil kemampuan pemecahan masalah Fisika kelompok siswa yang diberi bentuk penilaian autentik portofolio; (4) khusus kelompok siswa yang memiliki high order thinking skill (HOTS) rendah, hasil kemampuan pemecahan masalah Fisika kelompok siswa yang diberi bentuk penilaian autentik kinerja lebih rendah dari hasil kemampuan pemecahan masalah Fisika kelompok siswa yang diberi bentuk penilaian autentik portofolio.
\end{abstract}

\section{Kata kunci}

bentuk penilaian autentik, high order thinking skill (HOTS), hasil pemecahan masalah Fisika, kinerja dan portofolio. 


\section{Pendahuluan}

Penilaian autentik disebut juga sebagai penilaian portofolio, penilaian proyek dan penilaian kinerja. Orientasi dari penilaian autentik adalah penilaian proses atau penilaian hasil belajar. Fokus dari penilaian autentik pada kemampuan perkembangan peserta didik dalam belajar. Penilaian autentik merupakan penilaian terhadap kompetensi siswa dalam melaksanakan proses pembelajaran dengan cara mengamati kegiatan siswa sehingga dapat mencerminkan kemampuan siswa yang sebenarnya. Sementara menurut Siswono (2010: 5I) asesmen autentik adalah penilaian performance dengan mengukur pengetahuan serta keterampilan siswa dalam penerapan pengetahuan dan keterampilan di kehidupan.

Dantes (2008: 4) menyatakan penilaian kinerja merupakan produk hasil dari proses. Artinya, penilaian kinerja merupakan hasil kerja dalam proses pelaksanaan program yang berdasarkan pemantauan terhadap perkembangan dan pencapaian program. Menurutnya pula ada tiga komponen utama dari penilaian kinerja, yaitu: tugas kinerja, rubrik performa, dan cara penilaian.

Berdasarkan penelitian pada pembelajaran siswa SDN di Kecamatan Penebel Tabanan tahun ajaran 2013/20I4 siswa kelas $V$ pada SDN Gugus 7 yang mengikuti pembelajaran konvensional dan siswa yang mengikuti pembelajaran berbasis kinerja terjadi perbedaan yang signifikan (Puspita, Winda dan Darsana, 2014: I).

Sementara itu penilaian portofolio adalah penilaian yang dilakukan oleh guru dalam dengan cara siswa melakukan koleksi terhadap pekerjaannya dalam bentuk sekumpulan dokumen dan atau karya peserta didik secara sistematik dan terorganisir disusun dalam jangka waktu tertentu seiring dengan perkembangan peserta belajar saat berlangsung, dan portofolio tersebut berguna bagi guru maupun peserta didik dalam penilaian dan monitoring kemajuan ilmu pengetahuan, keahlian, serta sikap peserta didik.

Keterampilan dalam menyelesaikan masalah menurut Polya (1973: xvii), yaitu; suatu keahlian berpikir yang menggunakan empat tahap menyelesaikan masalah yaitu: I) Understanding the problem, 2) Devising plan, 3) Carrying out the plan,
4) Looking Back, yaitu: tahap pertama keterampilan dalam memahami masalah, kemudian tahap kedua membuat rencana penyelesaian masalah, selanjutnya melaksanakan penyelesaian masalah berdasarkan rencana yang telah di tetapkan, dan tahap keempat adalah memeriksa kembali pelaksanaan penyelesaian masalah apakah sudah sesuai dengan hasil yang di harapkan.

Krulik dan Rudnick (1988: 18-28) berpendapat bahwa memecahkan masalah dapat diselesaikan melalui suatu proses yang dianalisis dan direpresentasikan melalui beberapa tahap, yaitu: membaca (read), merencanakan suatu kemampuan akademik (explore), memilih strategi mana yang akan digunakan (select a strategy), menemukan jawaban atau penyelesaian (solve), peninjauan kembali jawaban yang sudah diperoleh, dan memperluas jawaban (Look back and extend).

Dengan demikian bahwa keahlian dalam menyelesaikan masalah, yaitu: keahlian dalam menuntaskan masalah dengan mengurai masalah, membuat rencana langkah penuntasan masalah, menentukan strategi penyelesaian masalah, menyelesaikan masalah, dan melakukan pemeriksaan terhadap hasil penyelesaian masalah.

Keterampilan menyelesaikan masalah manfaatnya besar terhadap siswa dalam melihat relevansi antara Fisika dengan pelajaran lain serta kehidupan nyata. Menurut Slameto (1991: 144) siswa dalam menyelesaikan masalah mendapatkan manfaat, yaitu: (a) siswa dapat mempelajari cara cara dalam penyelesaian masalah saat menghadapi suatu masalah dan kemungkinan solusi yang mungkin terhadap suatu masalah, (b) siswa terlatih untuk melakukan eksplorasi, berpikir komprehensif, dan bernalar secara logis, (c) mengasah keahlian komunikasi dan mencapai nilainilai sosial melalui kelompok kerja, (d) membantu murid-murid yang pencapaiannya rendah agar memahami konsep dan mahir dalam pembelajaran Matematika, dan (e) membimbing mereka untuk memahami Matematika dalam menyelesaikan masalah.

Hal ini berarti manfat dapat diperoleh siswa dengan memecahkan masalah, yaitu: siswa akan belajar berbagai cara untuk menyelesaikan masalah, memungkinkan akan terlatih dan terbiasa 
dalam menghadapi soal baik yang sulit dan akan membantu dalam memahami konsep yang susah baik pemahaman maupun perhitungan seperti soal-soal Fisika.

Pelajaran Fisika adalah pelajaran yang tercantum dalam kurikulum Sekolah Menengah Atas (SMA) dan menjadi bagian struktur dari kurikulum yang siswa pelajari. Pelajaran Fisika selama ini termasuk pelajaran yang oleh siswa dianggap sulit, sebab dianggap untuk mempelajarinya perlu pemikiran yang mendalam.

High Older Thinking Skill (HOTS) atau Keahlian Berpikir Tingkat Tinggi, yaitu: model berpikir yang tidak sekedar mengingat informasi, namun melibatkan siswa pada tingkatan yang paling tinggi dalam berpikir untuk mengembangkan lingkungan belajar di mana siswa menjadi pencipta gagasan baru, penganalis informasi, dan generator pengetahuan. Menurut Heong et al (2000: II4) siswa yang lemah dalam HOTS tidak dapat menyelesaikan tugas-tugas berdasarkan kognitif dan metakognitif efektif, dampaknya prestasi akademik akan terpengaruh. Padahal menghasilkan beberapa ide-ide telah menjadi kebutuhan bagi setiap siswa untuk menyelesaikan tugas sekolah mereka. Akibatnya, mengatasi kesulitan dalam menghasilkan ide-ide adalah sangat penting. Sebagai solusinya, siswa perlu belajar HOTS untuk mengatasi kesulitan dalam menghasilkan ide-ide tersebut. Hal ini karena HOTS adalah proses metakognitif yang mengajarkan bagaimana menggunakan metode mengamati dan belajar memproses informasi dengan menggunakan ide yang berkembang.

Mengacu kepada hasil observasi di SMA Negeri 2 Depok diketahui bahwa setiap menjelang tes siswa terdorong untuk menghafal karena penilaian ditekankan pada penguasaan konsep dengan tes dalam bentuk tertulis sebagai tolok ukur penilaian. Oleh karenanya guru dituntut untuk membuat terobosan dalam mencari atau memilih teknik penilaian yang cocok agar penilaian yang dilakukan benar-benar dapat mengukur sejauh mana ketercapaian atau kemampuan siswa. Penilaian autentik kinerja dan portofolio diharapkan dapat dijadikan terobosan untuk memenuhi kebutuhan penilaian tersebut. Selain itu, guru juga jarang melakukan pembelajaran kelas maupun di luar laboratorium yang bertujuan melibatkan kemampuan siswa dalam mengobservasi, memahami, dan mengorganisasikan fenomena-fenomena yang dijumpai di luar ruangan belajar.

Dalam rangka memperkaya teori-teori mengenai pemecahan masalah pada pelajaran Fisika, bentuk penilaian autentik dan high order thingking skill perlu dipandang penting sehingga perlu adanya kajian dan penelitian tentang ketiga aspek tersebut. Sehingga peneliti tertarik meneliti tentang penilaian autentik dalam bentuk kinerja maupun portofolio dengan dihubungkan ke dalam kompetensi pemecahan masalah Fisika dan high order thingking skill (HOTS) siswa.

Tujuan dari penelitian ini agar dapat memberikan gambaran bagi guru Fisika di tingkat menengah tentang efektifitas bentuk penilaian autentik kinerja maupun bentuk penilaian autentik portofolio, sehingga dapat memberikan informasi kepada pengambilan keputusan, serta dapat dijadikan bahan pertimbangan dalam upaya meningkatkan hasil kemampuan memecahkan masalah Fisika pada siswa SMA.

Selain itu, diharapkan penelitian ini dapat menjadi bahan masukan guna penyempurnaan pembelajaran Fisika, memperjelas pemahaman variabel penelitian guna memperlancar proses pembelajaran, serta memacu mutu kualitas hasil belajar mata pelajaran Fisika, dan memberikan siswa kemampuan dalam mengasah kemampuan high order thinking skill (HOTS).

\section{Metode Penelitian}

Penelitian ini dirancang dengan metode eksperimen dengan desain treatment by level $2 \times$ 2 (two way level design). Variabel perlakuan dalam penelitian ini adalah bentuk penilaian autentik, sedangkan variabel atribut high order thinking skill (HOTS). Variabel terikat adalah kemampuan pemecahan masalah Fisika.

Populasi target dalam penelitian ini adalah seluruh siswa SMAN 2 Kota Depok. Sedangkan populasi terjangkau adalah kelas XI di SMAN 2 Depok yang terdiri dari 6 kelas dengan jumlah siswa 224 siswa. Semua siswa kelas XI tersebut memiliki peluang yang sama untuk terpilih sebagai sampel dalam perlakuan ini. 
Teknik pengambilan sampel dalam penelitian ini menggunakan teknik multi stage sampling, yaitu: dengan cara dua tahap, tahap pertama dengan random sampling terhadap kelas dari enam kelas menjadi empat kelas dan tahap kedua dengan random sampling terhadap empat kelas menjadi masing-masing diambil dua kelas. Tahap pertama sebagai sampel dilakukan random terhadap siswa kelas XI. Mula-mula siswa yang sudah dikelompokkan dari sekolah perkelas yang telah menjadi 6 kelas, antara lain kelas: XI MIPAI, XI MIPA2, XI MIPA3, XI MIPA4, XI MIPA5, dan XI MIPA6 diberikan instrumen high order thinking skill (HOTS), kemudian dihitung variannya tiap kelas untuk menentukan mana kelas yang akan dilakukan penelitian karena akan diambil empat kelas, yaitu: dua kelas untuk belajar dengan menggunakan bentuk penilaian kinerja dan dua kelas untuk belajar menggunakan bentuk penilaian portofolio. Berdasarkan hasil pengujian varian dengan menggunakan program excel diperoleh varian untuk kelas: $X$ MIPAI $=22,012, X I$ MIPA2 $=9,842$, XI MIPA3 $=1,949$, XI MIPA4 $=1,725$, XI MIPA5 $=1,682$, dan XI MIPA6 = I,734. Berdasarkan nilai varian setiap kelas tersebut maka kelas yang diambil sebagai sampel penelitian adalah kelas: XI MIPA3, XI MIPA4, XI MIPA5, dan XI MIPA6 karena memiliki varian yang hampir sama atau berdekatan nilainya. Kemudian tahap kedua dilanjutkan untuk menentukan mana kelas sampel yang diberikan eksperimen penilaian autentik kinerja dan portofolio ditentukan dengan random sampling terhadap empat kelas, didapat penilaian autentik kinerja adalah kelas: XI MIPA3 dan XI MIPA5 serta penilaian autentik portofolio adalah kelas: XI MIPA4 dan XI MIPA6.

Dengan demikian sudah terbentuk dua kelas siswa untuk eksperimen dengan belajar menggunakan penilaian autentik kinerja dan dua kelas untuk penilaian portofolio. Selanjutnya untuk menentukan siswa yang memiliki high order thinking skill (HOTS) tinggi dan siswa yang memiliki high order thinking skill (HOTS) rendah, siswa diberikan instrumen high order thinking skill (HOTS) berupa soal uraian yang mengukur High order thinking skill (HOTS) kemudian hasil skornya diurutkan dari skor tertinggi ke skor terendah, kemudian siswa baik pada kelompok eksperimen dengan kinerja maupun portofolio dikelompokkan dalam kelompok yang memiliki high order thinking skill tinggi dan kelompok yang memiliki high order thinking skill rendah.

Cara untuk memperoleh kelompok high order thinking skill tinggi dan kelompok yang memiliki high order thinking skill rendah adalah dengan membagi peserta $(M)$ menjadi tiga bagian yang sama besar, di mana $\mathrm{Mt}=\mathrm{Mr}$ (kelompok tinggi=kelompok rendah). Menurut Naga (2012: 278-279), ukuran yang terbaik untuk menentukan kelompok tinggi dan kelompok rendah dengan $27 \%$, di mana angka ini cukup kontras dan reliabel. Oleh karena itu, penarikan sampel dilakukan dengan mengambil $27 \%$ siswa yang memiliki high order thinking skill tinggi dan $27 \%$ siswa yang memiliki high order thinking skill rendah. Jumlah sampel yang terpilih pada setiap sel sesuai sengan rancangan penelitian adalah 20 siswa sehingga jumlah sampel adalah 80 siswa.

Eksperimen dilakukan dengan cara memberi perlakukan berupa teknik penilaian autentik kinerja dan autentik portofolio secara sitematis sebanyak empat kali dalam masa empat kali pertemuan pembelajaran. Dalam penelitian ini terdapat dua macam data yang dikumpulkan melalui instrumen penelitian, yaitu: pertama instrumen kemampuan pemecahan masalah Fisika terdiri dari lima butir soal uraian dengan kunci jawaban sesuai pertanyaan yang sudah tervalidasi baik dari pakar maupun empirik pada pokok bahasan fluida dinamis dan kedua instrumen high order thinking skill (HOTS) sebanyak enam butir soal yang sudah tervalidasi oleh pakar dan empirik yang diambil dari materi-materi pokok bahasan yang sudah dipelajari sebelum fluida dinamis baik kelas X dan kelas XI mata pelajaran Fisika.

Normalitas data diuji dengan menggunakan uji Lilliefors, sedangkan homogenitas varians diuji dengan menggunakan uji Bartlett. Hipotesis penelitian diuji dengan menggunakan teknik analisis varians (ANAVA) dua jalur dilanjutkan dengan uji pengaruh sederhana (simple effect) menggunakan uji t-Dunnet. 


\section{Hasil Penelitian Dan Pembahasan}

Hasil pengujian hipotesis penelitian menggunakan teknik analisis varians (ANAVA) dapat dilihat pada Tabel I berikut:

Tabel I. Hasil Perhitungan Analisis Varian (ANAVA) Dua Jalan pada $\alpha=0.05$

\begin{tabular}{|c|r|r|r|l|r|}
\hline \multirow{2}{*}{$\begin{array}{c}\text { Sumber } \\
\text { Varian }\end{array}$} & JK & db & RJK & $\mathbf{F}_{\text {hitung }}$ & $\mathbf{F}_{\text {Tabel }}$ \\
\cline { 2 - 6 } & & & & & 0,05 \\
\hline $\begin{array}{c}\text { Antar } \\
\text { Kolom } \\
\text { (A) }\end{array}$ & 57,8 & $\mathrm{I}$ & 57,8 & 18,4184 & 3,96676 \\
\hline $\begin{array}{c}\text { Antar } \\
\text { Baris (B) }\end{array}$ & 96,8 & $\mathrm{I}$ & 96,8 & $30,846 \mathrm{I}$ & 3,96676 \\
\hline AB & 224,45 & $\mathrm{I}$ & 224,45 & 71,5229 & 3,96676 \\
\hline D & 238,5 & 76 & 3,13816 & & \\
\hline TOTAL & 617,55 & 79 & & & \\
\hline
\end{tabular}

Sebagai konsekuensi terjadinya interaksi, maka perlu dilakukan uji pengaruh sederhana (simple effect) untuk menguji perbedaan hasil kemampuan pemecahan masalah Fisika antara kelompok siswa yang memiliki high order thinking skill (HOTS) tinggi, yang diberi bentuk penilaian autentik kinerja dan yang diberi penilaian autentik portofolio, dan perbedaan hasil kemampuan pemecahan masalah Fisika untuk kelompok siswa yang memiliki high order thinking skill (HOTS) rendah, yang diberi penilaian autentik kinerja lebih dan yang diberi penilaian autentik portofolio. Hasil uji t-Dunnet dapat dirangkum dalam Tabel 2 berikut:

\section{Tabel 2. Rangkuman Hasil Uji t Dunnet}

\begin{tabular}{|c|c|c|c|}
\hline $\begin{array}{l}\text { Perbandingan } \\
\text { Kelompok }\end{array}$ & \multicolumn{2}{|c|}{ Uji t-Dunnet } & Simpulan \\
\cline { 2 - 3 } & $\mathrm{t}_{\text {hitung }}$ & $\begin{array}{l}\mathrm{T}_{\text {tabel }} \\
(0,05)\end{array}$ & \\
\hline AIBI-A2BI & 9,018 & $\mathrm{I}, 992$ & Tolak $\mathrm{H}_{0}$ \\
\hline AIB2-A2B2 & 2,950 & $\mathrm{I}, 992$ & Tolak $\mathrm{H}_{0}$ \\
\hline
\end{tabular}

Berdasarkan hasil analisis varians (ANAVA) Artinya dapat dikatakan bahwa terdapat perbedaan kemampuan pemecahan masalah Fisika kelompok siswa yang diberi bentuk penilaian autentik kinerja $\left(A_{1}\right)$ dengan kemampuan pemecahan masalah Fisika kelompok siswa yang diberi bentuk penilaian autentik portofolio $\left(A_{2}\right)$. Selanjutnya untuk meyakinkan adanya perbedaan tersebut, maka dilanjutkan dengan uji t-Dunnet.
Hal ini mempunyai arti bahwa kemampuan pemecahan masalah Fisika siswa yang diberi bentuk penilaian autentik kinerja lebih tinggi daripada siswa yang diberi penilaian autentik portofolio pada kelompok siswa yang memiliki high order thinking skill (HOTS) tinggi.

Berdasarkan penjelasan di atas dapat disimpulkan bahwa hasil kemampuan pemecahan masalah Fisika bentuk penilaian autentik kinerja lebih tinggi dari hasil kemampuan pemecahan masalah Fisika kelompok siswa yang diberi bentuk penilaian autentik portofolio. Hal ini dapat dikemukakan secara jelas melalui pembahasan berikut:

Bentuk penilaian autentik kinerja diterapkan di kelas sedapat mungkin dianalogikan dengan kegiatan pembelajaran yang melibatkan siswa dengan tujuan untuk mendorong siswa agar dapat lebih aktif dalam mengekspresikan perasaannya melalui proses pembelajaran dengan menggunakan praktikum pada mata pelajaran Fisika pokok bahasan fluida dinamis.

Pada penelitian ini bentuk penilaian autentik kinerja pada dasarnya merupakan penilaian yang dilakukan oleh guru terhadap kemampuan pemecahan masalah Fisika khususnya dalam fluida dinamis secara individu untuk melihat perkembangan satu periode. Pada periode tersebut terdapat proses penilaian yang dilakukan oleh guru untuk menggali kemampuan siswa dalam melakukan suatu proses kegiatan pembelajaran dengan melakukan suatu keterampilan melibatkan siswa langsung secara nyata, karena langsung melakukannya dengan praktik, di sini memungkinkan siswa tidak lagi berpikir secara abstrak tapi nyata, karena siswa berhubungan langsung dengan objek yang dipelajari. Proses ini dapat dilakukan siswa misalnya di laboratorium Fisika pada saat melakukan praktikum. Dengan demikian siswa berarti melihat sendiri benda yang dipelajari, alat yang digunakan, prosedur yang dilakukan, dan apa yang dihasilkan dalam pengamatan tersebut, sehingga siswa mengalami sendiri apa yang dipelajarinya. Hal ini akan melatih siswa terbiasa untuk berpikir, untuk melakukan pengamatan dengan panca indra yang mereka miliki dan akan diingat apa yang mereka lakukan pada saat 
pembelajaran dan juga akan meningkatkan pemahaman mereka dalam menguasai suatu konsep materi karena sudah langsung melihat dan mengerjakan sendiri dengan melihat objeknya.

Penggunaan penilaian autentik kinerja juga akan memotivasi siswa untuk terampil dan memecahkan setiap masalah yang mereka hadapi. Hal ini akan membuat siswa senang dan akan termotivasi untuk terus melakukan pemecahan masalah yang diberikan kepada siswa. Sementara bagi guru dalam bentuk penilaian autentik kinerja dapat membuat rubrik sesuai dengan kompetensi apa yang akan diukur dari siswa. Hal ini akan membantu guru untuk mengukur apa yang hendak diukur terutama dari keterampilan atau psikomotor siswa.

Sebaliknya, penilaian dengan menggunakan portofolio, siswa hanya sekedar mengumpulkan tugas-tugas dengan mengoleksi saja. Dari tugastugas yang dibuat portofolio tidak ada yang di praktikkan atau dibuat nyata. Siswa masih berpikir secara abstrak tidak nyata, karena siswa tidak berhubungan langsung dengan objek yang dipelajari. Siswa tidak diarahkan untuk berpikir analisis, untuk bekerja dengan panca indranya dalam sebuah praktikum dan dalam langsung berhubungan dengan objek yang nyata. Dengan demikian penilaian semacam ini tidak membuat siswa belajar secara nyata seperti penilaian unjuk kerja atau kinerja. Sehingga kemampuan memecahkan persoalan pelajaran Fisika yang dimiliki kurang terlaksana dengan baik.

Selanjutnya, hasil kemampuan pemecahan masalah Fisika juga dipengaruhi oleh high order thinking skill (HOTS) yang dimiliki siswa. Artinya penilaian autentik dan high order thinking skill (HOTS) berpengaruh terhadap kemampuan pemecahan masalah Fisika. Berdasarkan analisis varians (ANAVA) dua jalan ditemukan bahwa $F_{\text {hitung }}$ interaksi $A B$ lebih besar dari $F_{\text {tabel }}$. Ini mempunyai arti bahwa terdapat pengaruh interaksi yang signifikan antara bentuk penilaian autentik dan high order thinking skill (HOTS) terhadap kemampuan pemecahan masalah Fisika. Karena terdapat pengaruh interaksi yang signifikan, maka dilanjutkan dengan uji simple effect, yaitu: menguji (I) perbedaan hasil kemampuan pemecahan masalah Fisika kelompok siswa yang diberi bentuk penilaian autentik kinerja dengan hasil kemampuan pemecahan masalah Fisika kelompok siswa yang diberi bentuk penilaian autentik portofolio pada kelompok siswa yang memiliki high order thinking skill (HOTS) tinggi dan (2) perbedaan hasil kemampuan pemecahan masalah Fisika kelompok siswa yang diberi bentuk penilaian autentik kinerja dengan hasil kemampuan pemecahan masalah Fisika kelompok siswa yang diberi bentuk penilaian autentik portofolio pada kelompok siswa yang memiliki high order thinking skill (HOTS) rendah.

Berdasarkan analisis varian (ANAVA) dua jalan pada kelompok siswa diperoleh $F_{\text {hitung }}$ 30,846I lebih besar dari $F_{\text {tabel }}$ pada $\alpha 0.05=$ 3,96676. Ini menunjukkan terdapat perbedaan kemampuan pemecahan masalah Fisika antara siswa yang yang memiliki high order thinking skill (HOTS) tinggi dan siswa yang yang memiliki high order thinking skill (HOTS) rendah. Perbedaan ini ditunjukkan dengan skor rata-rata hasil kemampuan pemecahan masalah Fisika kelompok siswa yang diberi bentuk penilaian autentik kinerja sebesar 19,03 dan skor rata-rata hasil kemampuan pemecahan masalah Fisika kelompok siswa yang diberi bentuk penilaian autentik portofolio sebesar 17,33. Ini mempunyai arti bahwa khusus kelompok siswa yang memiliki high order thinking skill tinggi, terdapat perbedaan yang berarti antara hasil kemampuan pemecahan masalah Fisika kelompok siswa yang diberi bentuk penilaian autentik kinerja dengan hasil kemampuan pemecahan masalah Fisika kelompok siswa yang diberi penilaian autentik portofolio. Perbedaan ini dilanjutkan dengan Uji t-Dunnet yang hasilnya menunjukkan bahwa nilai $t_{\text {hitung }} 9,018$ lebih besar dari $t_{\text {tabel }}$ l.992. Ini mempunyai arti bahwa khusus kelompok siswa yang memiliki high order thinking skill tinggi, rata-rata hasil kemampuan pemecahan masalah Fisika kelompok siswa yang diberi bentuk penilaian autentik kinerja lebih tinggi dari rata-rata hasil kemampuan pemecahan masalah Fisika kelompok siswa yang diberi penilaian autentik portofolio.

Seperti yang sudah dikemukakan pada penjelasan di atas data nilai hasil kemampuan pemecahan masalah untuk kelompok siswa yang 
diberi bentuk penilaian kinerja dan hasil kemampuan pemecahan masalah Fisika dengan bentuk penilaian portofolio tanpa melihat high order thinking skill yang dimiliki siswa. Selain karena perbedaan karakteristik penilaian kinerja dan portofolio yang dampaknya berbeda terhadap siswa, juga high order thinking (HOTS) yang dimiliki siswa akan berperan terhadap pemecahan masalah Fisika.

High order thinking skill atau keterampilan berpikir tingkat tinggi adalah proses berpikir yang tidak sekedar menghafal dan menyampaikan kembali informasi yang diketahui. Yang termasuk ke dalam kemampuan berpikir tingkat tinggi menurut Sunaryo (20I4: 42) adalah kemampuan berpikir kritis dan kreatif siswa dapat dilatih dengan pembelajaran yang menuntut siswa untuk melakukan eksplorasi, inkuiri, penemuan, dan memecahkan persoalan serta melalui belajar dalam kelompok kecil dengan menerapkan pendekatan scaffolding kemudian tugas yang menuntut strategi kognitif dan metakognitif siswa.

Dalam aktivitas memecahkan persoalan bahwa keterampilan berpikir kreatif memungkinkan seorang individu memandang suatu persoalan dari berbagai perspektif sehingga memungkinkannya untuk menemukan solusi kreatif dari persoalan yang akan diselesaikan. Pentingnya kemampuan berpikir tingkat tinggi dalam aktivitas memecahkan persoalan siswa akan selalu mencari solusi agar persoalan dapat terselesaikan dengan baik. Dengan demikian kemampuan pemecahan masalah pada Fisika dibutuhkan siswa yang memiliki high order thinking skill yang tinggi.

Di sisi lain, pada kelompok siswa yang memiliki High order thinking skill rendah secara statistik menunjukkan bahwa terdapat perbedaan antara hasil kemampuan pemecahan masalah Fisika kelompok siswa yang diberi bentuk penilaian autentik kinerja dengan hasil kemampuan pemecahan masalah Fisika kelompok siswa yang diberi penilaian autentik portofolio. Perbedaan ini ditunjukkan dengan skor rata-rata hasil kemampuan pemecahan masalah Fisika kelompok siswa yang diberikan penilaian autentik kinerja sebesar 16,25 dan skor rata-rata hasil kemampuan pemecahan masalah Fisika kelompok siswa yang diberi penilaian autentik portofolio sebesar 17,90. Ini mempunyai arti bahwa khusus kelompok siswa yang memiliki High order thinking skill rendah, terdapat perbedaan antara hasil kemampuan pemecahan masalah Fisika kelompok siswa yang diberi bentuk penilaian autentik kinerja dengan hasil kemampuan pemecahan masalah Fisika kelompok siswa yang diberi penilaian autentik portofolio. Perbedaan ini dilanjutkan dengan Uji t-Dunnet yang hasilnya menunjukkan bahwa nilai $t_{\text {hitung }}=2,95$ lebih besar dari $t_{\text {tabel }} 1,992$ Ini mempunyai arti bahwa khusus kelompok siswa yang memiliki High order thinking skill rendah, perbedaan skor rata-rata hasil kemampuan pemecahan masalah Fisika kelompok siswa yang diberi bentuk penilaian autentik kinerja lebih rendah dari rata-rata hasil kemampuan pemecahan masalah Fisika kelompok siswa yang diberi penilaian autentik portofolio.

Kenyataan tersebut di atas dapat dijelaskan bahwa bentuk penilaian autentik kinerja merupakan suatu bentuk penilaian yang diberikan oleh guru kepada siswa dalam menyelesaikan pemecahan masalah dengan lebih menekankan kepada performance siswa dengan memaksimalkan penggunaan panca indra yang dimilikinya. Sehingga siswa melakukan pemikirannya dengan semaksimal mungkin karena harus berpikir dalam menyelesaikan pembelajarannya. Siswa harus mengamati, menghitung, menganalisis, dan membuat kesimpulan. Tentu saja penilaian kinerja ini akan memaksa siswa untuk berpikir lebih keras lagi dalam pelaksanaannya. Sehingga untuk siswa yang memiki high order thinking skill rendah akan kurang termotivasi untuk melaksanakan hal-hal yang dilakukan pada penilaian kinerja. Hal ini dikarenakan siswa yang memiliki high order thinking skill rendah akan kesulitan untuk mengidentifikasi segala kegiatan yang dalam memecahkan masalah. High order thinking skill (HOTS) yang ada pada diri mereka, dapat mempengaruhi proses pemecahan masalah Fisika. Kenyataannya banyak di antara kelompok mereka yang tidak menyelesaikan soal-soal pemecahan masalah Fisika fluida dinamis dengan benar.

Sementara pada kelompok siswa yang diberi bentuk penilaian portofolio, mereka lebih menyukai karena siswa merasa tidak dituntut 
untuk berpikir yang cukup keras sebagaimana pada penilaian kinerja. Tetapi mereka terbantu proses pembelajarannya dengan menggunakan penilaian portofolio. Siswa akan merasa senang dengan penilaian portofolio karena siswa dilibatkan dalam penilaiannya dengan dapat menentukan sendiri apa yang mereka lakukan. Mereka merasa dapat diberi kesempatan untuk membuat portofolio dengan kreasi dan hobi mereka. Apalagi dengan kemudahan internet, buku-buku sumber pelajaran dan media ajar lainnya yang terkait dengan fluida dinamis akan lebih mudah didapatkan. Sedangkan untuk pemecahan masalah Fisika berupa soal-soal yang sulit mereka dapat terbantu dengan seringnya mereka latihan menyelesaikan soal-soal yang sama atau soal-soal yang mulai dari tingkatannya rendah sampai yang sulit. Sehingga kenyataannya siswa yang memiliki high high order thinking skill (HOTS) rendahpun dapat memiliki skor rata-rata pemecahan masalah Fisika yang lebih tinggi dengan menggunakan penilaian portofolio.

\section{Kesimpulan}

Berdasarkan hasil pengujian hipotesis, maka dapat disimpulkan beberapa hal sebagai berikut: (I) Hasil kemampuan pemecahan masalah Fisika antara kelompok siswa yang diberi perlakuan penilaian autentik kinerja lebih tinggi dari kemampuan pemecahan masalah Fisika dengan menggunakan penilaian autentik portofolio, (2) Terdapat pengaruh interaksi antara penilaian autentik dengan high order thinking skill (HOTS) terhadap kemampuan pemecahan masalah Fisika, (3) Khusus untuk kelompok siswa yang memiliki high order thinking skill (HOTS) tinggi, kemampuan pemecahan masalah Fisika antara siswa yang diberi penilaian autentik kinerja lebih tinggi dari kemampuan pemecahan masalah Fisika kelompok siswa yang diberi penilaian autentik portofolio, dan (4) Khusus untuk kelompok siswa yang memiliki high order thinking skill (HOTS) rendah, kemampuan pemecahan masalah Fisika antara siswa yang diberi penilaian autentik kinerja lebih rendah dari kemampuan pemecahan masalah Fisika kelompok siswa yang diberi penilaian autentik portofolio.

\section{Daftar Pustaka}

Dantes Nyoman. (2008). Hakikat Asesmen Otentik Sebagai Penilaian Proses dan Produk Dalam Pembelajaran Yang Berbasis Kompetensi, Makalah Disampaikan Pada In House Training (IHT) SMA N I Kuta Utara, https://www.academia.edu/2227/855/hakika t_asesmen_otentik_sebagai_penilaian_pros es, I-18.

Heong, Yee Mei et. all. (20I5). The Effectiveness Of Higher Order Thinking Skills For Generating Idea Among Technical Students, Recent Advances in Educational Technologies, http://eprints.uthm.edu.my/7448/I/yee_mei heong U.pdf, II3-II8.

Krulik, Stephen dan Jesse A. Rudnick. 1988. Problem Solving: A Handbook For Elementary School Teachers. Boston: Allyn and Bacon.

Naga, Dali S. (20I2). Teori Sekor Pada Pengukuran Mental. Jakarta: PT. Nagarani Citrayasa.

Polya, George. (1973). How to solve it A New Aspect of Mathematical Method (England: Stanford university.

Puspita, Mita, I Wyn. Rinda, dan I Wyn. Darsana. (20I4). Pengaruh Penerapan Pembelajaran Berbasis Penilaian Kinerja Terhadap Hasil Belajar IPA Siswa Kelas V Pada Gugus 7 Kecamatan Penebel Kabupaten Tabanan Tahun Ajaran 20I3/20I4, 2(I):I-I 2.

Siswono,Tatag Y. E. (2002). Penilaian Autentik dalam Pembelajaran Kontekstual Jurnal Nasional "MATEMATIKA, Jurnal Matematika atau Pembelajarannya", Tahun VIII, Universitas Negeri Malang Konferensi Nasional Matematika, XI: 5I-57.

Slameto. (1991). Proses Belajar Mengajar Dalam Sistem Kredit Semester (SKS). Jakarta: Bumi Aksara.

Sunaryo, Yoni. (2014). Model Pembelajaran Berbasis Masalah Untuk Meningkatkan Kemampuan Berpikir Kritis dan Kreatif Matematik Siswa SMA Di Kota Tasikmalaya, Jurnal Pendidikan dan Keguruan, I (2): hh. $4|-5|$. 